HEAT DILATATION OF METALS FROM LOW tration), and immersed in a freezing mixture of three each case, both longitudinal and transverse, was

By Thomas AnDRews, F.R.S.

IT is understood that the coefficients of heat dilata- tained in separate jacketed freezing tanks at a tempeIT is understood that the coefients of heat dilata- rature of $-18^{\circ} \mathrm{C}$. The vessel, A, containing the bars tion increase with rise of temperature; but Professor
P. G. Tait, in his recent work on Heat, page 8\%, re-- ther surrounded by another compartment holding a
marks that " we are not a ware of any experiments
quantity of a freezing mixture of snow and salt at a marks that "we are not aware of any experiments made with a view of deciding whether, as is probable, temperature of $-20^{\circ} \mathrm{C}$. By this means and by at a

Tadle I. -Analyses of Wrovght Iron, Steels, and Cast MEtals miployed. Rolled Burs.

\begin{tabular}{|c|c|c|c|c|c|c|c|c|c|c|}
\hline Description. & & $\begin{array}{c}\text { Graphitic } \\
\text { Carbon. }\end{array}$ & $\begin{array}{l}\text { Combined } \\
\text { Carbon. }\end{array}$ & silicon. & Sulphur. & $\begin{array}{l}\text { Phos. } \\
\text { phorus. }\end{array}$ & $\begin{array}{l}\text { Jian- } \\
\text { ganese. }\end{array}$ & $\begin{array}{l}\text { Iron (by } \\
\text { Dif- } \\
\text { ference). }\end{array}$ & Total. & $\begin{array}{l}\text { Speciffc } \\
\text { Qravity. }\end{array}$ \\
\hline $\begin{array}{l}\text { Wrought iron (Wortley } \\
\text { scrap) }\end{array}$ & best & & None & 0:392 & 0.034 & 0.27 & 0.104 & $99 \cdot 11$ & 100 & 7.59 \\
\hline Ressemer steel, soft" & $\cdots$ & - & $0 \cdot 15$ & 0.009 & 0.112 & 0.085 & 0.468 & $99 \cdot 173$ & 100 & 7.853 \\
\hline 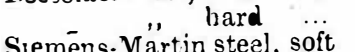 & & - & 0.48 & 0.121 & $0 \cdot 096$ & 0.089 & 0.684 & $98 \cdot 530$ & 100 & 7.838 \\
\hline $\begin{array}{l}\text { Siemēns.Martin steel, soft } \\
\text { hard }\end{array}$ & ... & $\overline{-}$ & $\begin{array}{l}0 \cdot 2: 3 \\
0 \cdot 46\end{array}$ & 0.014 & $\begin{array}{ll}01 \\
0.023\end{array}$ & 0.075 & $\begin{array}{l}0.698 \\
0.9-2\end{array}$ & $\begin{array}{l}98 \cdot 883 \\
98 \cdot 363\end{array}$ & 100 & $\begin{array}{l}7 \cdot 856 \\
7 \cdot 845\end{array}$ \\
\hline Cast st eel, soft ... & $\ldots$ & 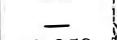 & $\begin{array}{l}0.46 \\
0.45\end{array}$ & $\begin{array}{l}0.101 \\
0.016\end{array}$ & $\begin{array}{l}0.023 \\
0.027\end{array}$ & $\begin{array}{ll}-1 & \\
0.048 & 0.5 \\
0.048\end{array}$ & $\begin{array}{l}0.086 \\
0.08\end{array}$ & $99 \cdot 373$ & 100 & 7.863 \\
\hline ", hard ... & $\ldots$ & 0.259 & $1 \cdot 19+$ & $0 \cdot 175$ & 0.063 & 0.019 & 0396 & $97 \cdot 898$ & 100 & $7 \cdot 805$ \\
\hline $\begin{array}{c}\text { Cast metal, best ... } \\
\text { " common }\end{array}$ & $\cdots$ & $\begin{array}{l}2 \cdot 78 \\
2 \cdot 62\end{array}$ & $\begin{array}{l}0.39+ \\
0.6 i^{+}\end{array}$ & $\begin{array}{l}2.34 \\
1.94\end{array}$ & $\begin{array}{l}0 \\
0.09 \\
0.09\end{array}$ & $\begin{array}{l}0.58 \\
0.95\end{array}$ & $\begin{array}{l}0.45 \\
0.52\end{array}$ & $\begin{array}{l}93 \cdot 37 \\
93 \cdot 21\end{array}$ & $\begin{array}{l}100 \\
100\end{array}$ & $\begin{array}{l}7 \cdot 206 \\
7 \cdot 134\end{array}$ \\
\hline \multicolumn{11}{|c|}{ Hrunmered Forgings. } \\
\hline $\begin{array}{ccl}\text { Wrought } & \text { iron } & \text { (Wortley } \\
\text { scrap) } & \ldots & \ldots\end{array}$ & $\begin{array}{l}\text { best } \\
\ldots\end{array}$ & - & 0.0 .35 & 0.117 & 0019 & 0246 & $0 \cdot 1121$ & $99 \cdot 468$ & 100 & - \\
\hline
\end{tabular}

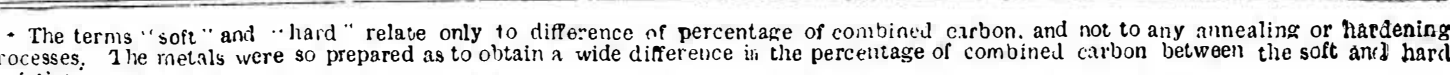

1 Combined carbon in theso samples was deter mined by commstion, and in the other samples by the colour teat.

TABLE II.

Rolled Bars.

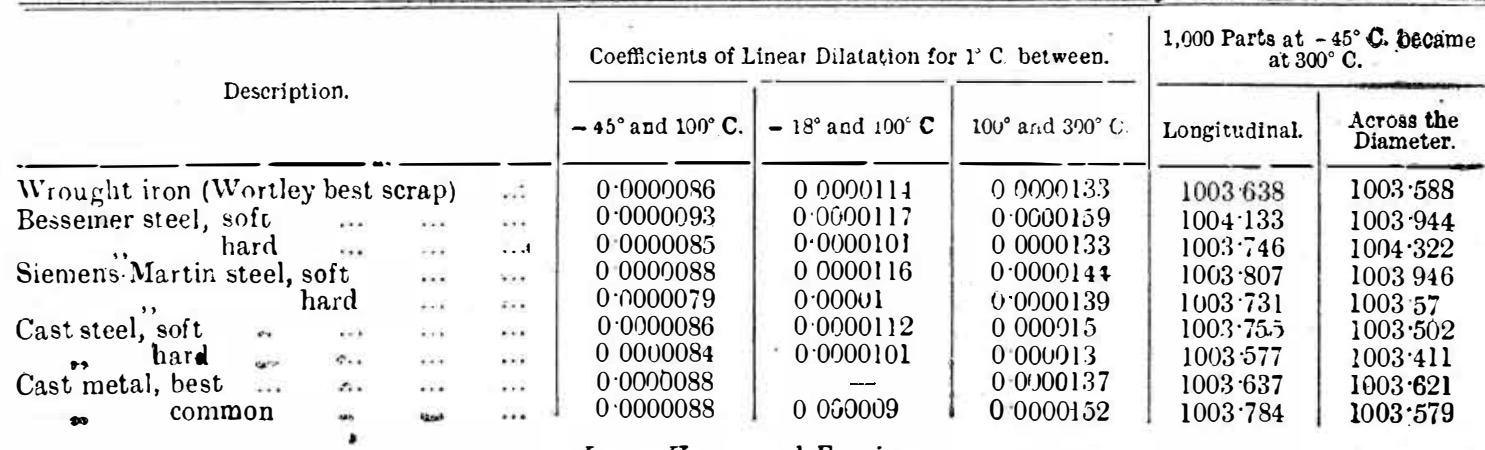

\begin{tabular}{|c|c|c|c|c|c|c|}
\hline & & Large $H a$ & $d$ Forgings & & & \\
\hline & & & & & 1,060 Parts a & became at \\
\hline & & & & & Lorgitudinal. & $\begin{array}{l}\text { Across the } \\
\text { Diameter. }\end{array}$ \\
\hline Vroughe iron (Wnitley & lest scripl). & 0.0000096 & 00000117 & $0.00001: 3 \mathrm{~J}$ & & \\
\hline essemer" & : & $\begin{array}{ll}0 \\
0.01 \\
0\end{array}$ & & & & \\
\hline emen-Martin stcel & $\ldots$ & $0.000009 ?$ & (1) O0n0!13 & 0.0000142 & 10039953 & 1003.641 \\
\hline
\end{tabular}

This was a smaller forging, onily 3 inches in sliameter aild 13 inches lour

Bath A for temperature of $-45^{\circ} \mathrm{C}$. Bath $\mathrm{B}$ for temperature of $-18^{\circ} \mathrm{C}$

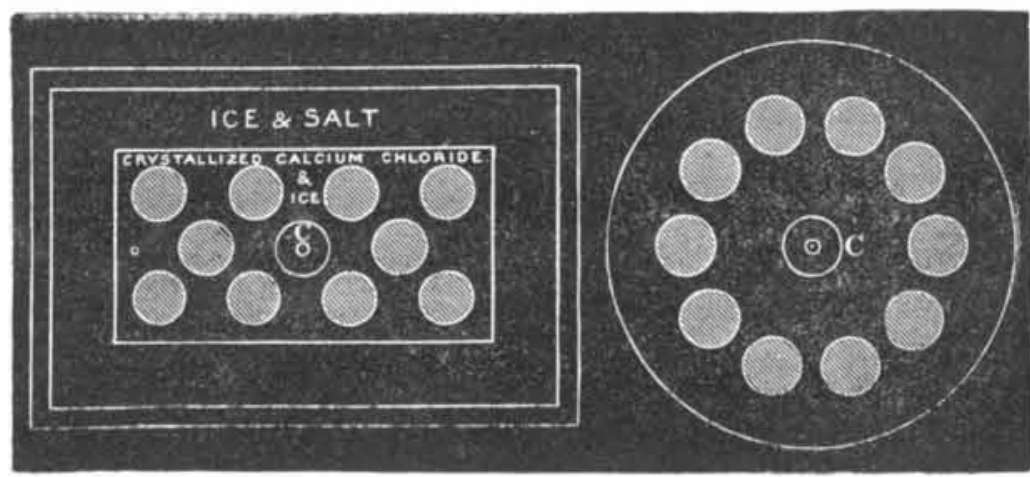

Ground Plan. Ground Plan.

Scale, $3 / 4$ inch $=1$ foot

these coefficients become gradually less as the tempera- $\mid$ stantly renewing the calcium chloride and snow mix ture is lowered below zero" $\left(0^{\circ}\right.$ C.) The following expe- ture during the experiments, a uniform temperature riments were made to investigate the subject in relation of $-45^{\circ} \mathrm{C}$., as registered by an alcohol thermometer,
to metals of the iron and steel series. The varieties of
was maintained for the experiments in the cold bath, modern steels manufactured by recent processes mani- A. Much larger cooling tanks of a snow capacity fo fest properties sufficiently diverse as almost to consti- each charge of $8 \mathrm{cwt}$. were used for the large forgings tute them distinct groups of metals, although for prac- and a large cast metal oil bath having a capacity of tical purposes they are conveniently grouped under tals have recently been so largely used for constructive The bars remained thus immersed in the freezing obtain an approximate quantitative estimation of their ascertained by another alcohol thermometer placed in obtain an approximate quantitative estimation of their
dilatation by heat through varied ranges of tempera- a hortained in the center of the test bar, $C$, wherein was also
ture. The rolled metals under observation in the ex- placed a little aleohol. When the bars had reached
phe ture. The rolled metals under observation in the ex-
periments consisted of round polished bars, 3 inches in little alcohol. When the bars had reached
and remained for some time at the registered temperaperiments consisted of round polished bars, 3 inches in
diameter and 13 inches long, planed perfectly square
ture of $-45^{\circ}$ C., each was in turn removed and placed diameter and 13 inches long, planed perfectly square
at each end ; they were carefully manipulated during $-45^{\circ}$ C., each was in turn removed and placed
on a suitable wooden frame, and its length instantly manufacture, and were selected from the author's and carefully measured by telescopic readings from a given in table I.
The $\begin{aligned} & \text { delicate micro-vernier gauge (deviations of }{ }^{2000} \text { of an } \\ & \text { inch were perceptible), also supported on a suitable } \\ & \text { rigid }\end{aligned}$ tions was from $45^{\circ} \mathrm{C}$ to $300^{\circ} \mathrm{C}$. The experiments time in the freezing mixture, and again removed, and were conducted as follows: For the measurements their diameter then carefully measured. No percepti commencing at the low temperature of $-45^{\circ}$ C., the ble alteration in the temperature of the bars occurred bars (having previously been slowly reduced to the during the very short time occupied in taking the ob-
temperature of $0^{\circ} \mathrm{C}$., and then gradually cooled to
servations, and frequent tests were made to ascertain temperature of $0^{\circ} \mathrm{C}$., and then gradually cooled to servations, and frequent tests were made to ascertain
$-18^{\circ} \mathrm{C}$.) were placed upright in the bath $\mathrm{A}$ (see illus-
this. The average of about thirty measurements in
The dimensions of the bars were taken in a similar nanner for the tempersture from $-18^{\circ} \mathrm{C}$, substituting in another cold bath, $\mathrm{B}$, a freezing mixture of now and salt to obtain this temperature, and using powdered ice and snow for the observations at $0^{\circ} \mathrm{C}$. by heating the whole of the bars in a large hot water bath for the period necessary to insure that their temperature throughout was as required, and the oil bath temperature errors was, as far as possible, carefully vuarded against by constant between the bath thermometers and that in the center of the test bar, and by keeping the bars immersed during sufficiently long periods.

The hammered metals under observation were large forgings of the different metals, $y$ feet 3 inches long, the ends and turned and polished bright. The measurements were taken on the total length of the forging, as in the case of the rolled metals, to insure greater accuracy, the experiments being conducted in somewhat similar manner; but owing to the greater length of the forgings, a modification of the method was made. One end of the forging was rigidly secured and
the expansion ascertained by measuring the diminishthe expansion ascertained by measuring the diminishing space between the other end of the forging and a
fixed point situated a distance from it. The results are fixed point situated
recorded in table II.

GENERAL REMARKS.

It is interesting to notice that the coefficients of diatation were greater in the case of the soft than the hard steels, a circumstance which may be accounted

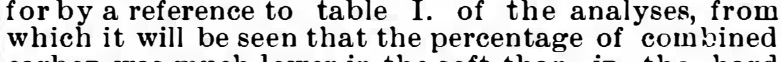
carbon was much lower in the soft than in the hard steels, the percentage of pure iron was consequently also greater in the soft steels; this caused them to be of a greater specific gravity. The results in table II. appear also to indicate another circumstance of metallurgical interest, viz., that the dilatation was generally
rather more in the direction of the length of the metallic cylinders than when measured across the diameter; result appears more unarked in the large round forgings of hammered steels and wrought iron than in the case of the rolled bars. It would therefore seem probable that the crystalline particles of the metals suffer slight permanent alteration of form in the direction of their ength during the process of rolling or drawing out, sufficient to very slightly affect their relative longitudinal and transverse low temperatures experimentally confirm the suges tion of Professor Tait, inasmuch as the coefficients of dilatation were found generally to decrease with the reduced temperature below $0^{\circ} \mathrm{C}$. The author also found such to be the case in his observations on the "Heat Dilatation of Pure Icef rom Very Low Temperatures," It may be remarked that many tons of the va-
rious freezing mixtures, snow, etc., were required for the experiments.

A NEW FORM OF SIEMENS FURNACE.* By JoHN HeAD.

IT would be necessary to write a complete history of the regenerative gas furnace to give any idea of the
diversity and difficulty of the problems which Sir William and Mr. Frederick Siemens had to solve before their furnace, now so well known to iron and steel manufacturers, was made available for use in metallurgical operations. Among these problems may be in-
stanced the preliminary heating of the gas as well as stanced the preliminary heating of the gas as well as
of the air, so as to introduce both of them into the heatthe to be given to the regenerators in order that the heat ical and rational manner, the arrangements for reversing the direction of the flame and for effecting a uniform diffusion of its heat throughout the heating chamber, all of which, simple as they now appear, in volved a large amount of careful consideration on the
part of the Messrs. Siemens. Besides these main feapart of the Messrs. Siemens. Besides these main fea-
tures that had to be discovered and applied, we are also indebted to them for all the details that constitute the indispensable accessories used in the construction and working of the regenerative gas furnace. By their work the employment of reactions and metallurgical operations, foreshadowed by chemical research, have been rendered possible and practicable, which but for their furnace could have had no practical application, and would therefore be unavailable to manufacturers.
The great economical idea embodied and carried out The great economical idea embodied and carried out trated by comparison with such a meritorious invention as Neilson's hot blast stove. In this case the separately burned for that purpose, but in the case of the Siemens regenerative gas furnace the heat below the temperature of the work carried on in the furnace up the gas and air supporting combustion. In high perature furnaces the heat below the temperature the work to be performed therein is by far the largest to the introduction of the produced, and previously had been lost by being allowed to pass away with the waste gases to the chimney. This circumstance was clearly explained by Lord Armstrong at the meeting heating the inflowing gas and air, the temperature of the flame in a furnace may be raised to almost any extent; in fact, the heat attainable nnder these condions is only limited by the power of resistance of the naterials of which the furnace is built. and thus the tions are obtained with facility by the expenditure of moderate amount of fuel, especially since the intro-
duction by $\mathrm{Mr}$. Frederick Siemens of the method of eating by radiation, by which means the durability heating by radiation, by which means the durabihty
of the furnace has also been much increased. In considering the details of construction of this ingenious * Paper recently read before the South Staffordshire Institute of Iron 
E. W. Harvey, who are on Mr. Frederick Siemens' the cause and source of the economy realized in a new but as in the new furnace a portion only of the technical staff, that possibly further economy in fuel furnace. If oxygen be admitted below the grate of a products of combustion passes away by the chimney, might be realized by a rearrangement of solne of the gas producer flled with incandescent coke (Fig. 6), car- while the remainder returns to the furnace after passwas directed to the conversion of solid fuel into the duce a certain quantity of heat. This carbonic acid sary for producing draught in the chimney is diminwas in the produer and to the relatively high tem- will be decomposed in the upper zone, and absorb a ished to the same extent This represents a further perature at which the products of combution in fuel. As there is no gas regenerator in the from the furnace into the regenerators, as also to the the weight of carbon gasified in the lower zone is equal new furnace, there is no loss of heat by radiation from chemical composition of these products, which tem- to that of the carbon gasified in the upper zone, and if it, and further economy is thereby also effected. In perature and gases they thought might be utilized in we suppress the production of carbonic acid and replace

As is well known, the production of carbonic oxide in in source of supply, half the fuel should be saved. the ordinary gas producer is the result of the decom-
position of the carbonic acid formed in the first in- air regenerators only, but must be distinguished from stance above the grate by incandescent carbon in the furnaces in which the air alone is heated. Such furupper portion of the producer, according to the equa- naces are necessarily wasteful, as only a portion of the perature is produced with the development of heat in heat contained in the burnt gases can ainable in practhe lower layers of the fuel, which is transformed with tice. In the new furnace, on the contrary, the gases the absorption of heat into carbonic oxide in travers- leaving the furnace are partly directed below the grate ing the red hot fuel above, while hydrocarbons are of the converter producer and partly into an air re-
distilled from the coal used, and leave the producer generator, so that the whole of the heat is utilized a

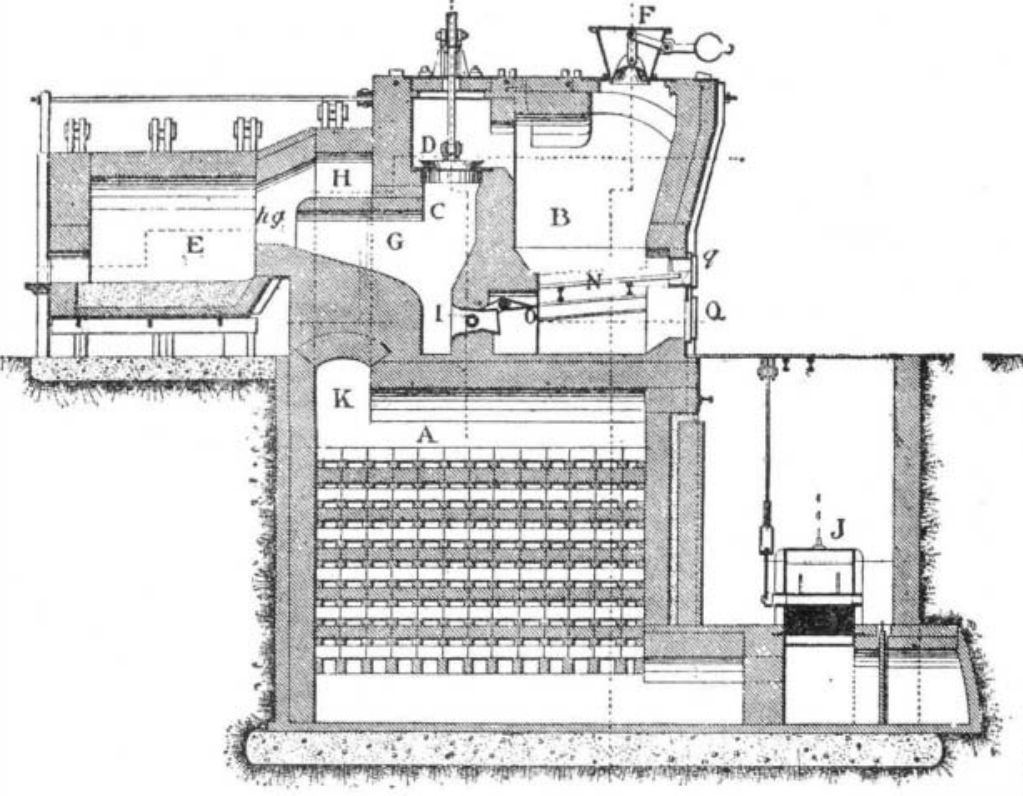

FIs. 1.

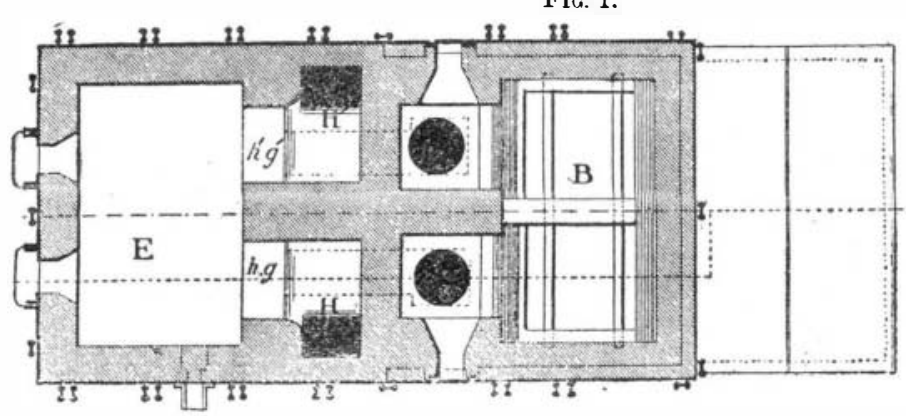

FIG. 3.

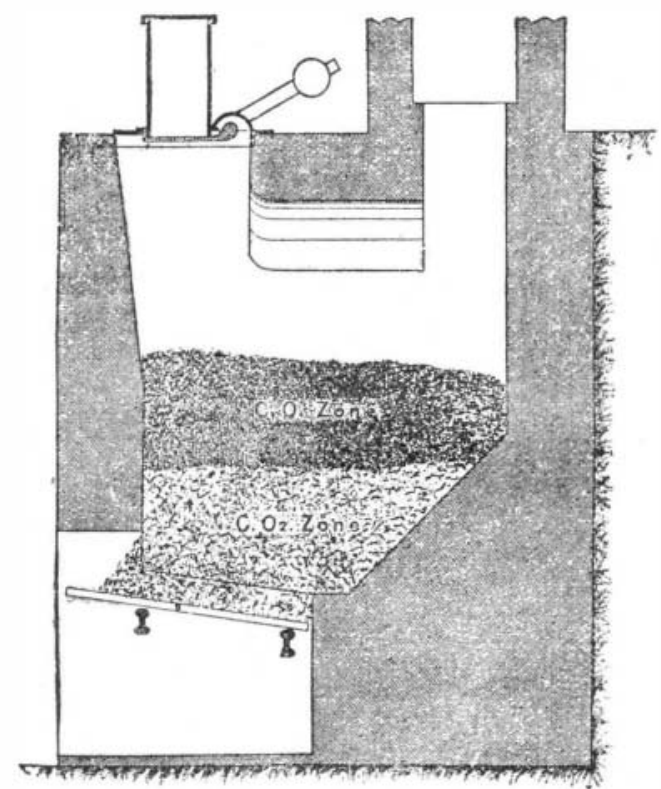

FIsi. G.

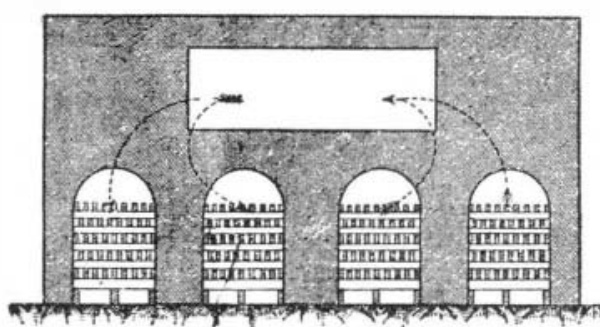

FIG. 7.

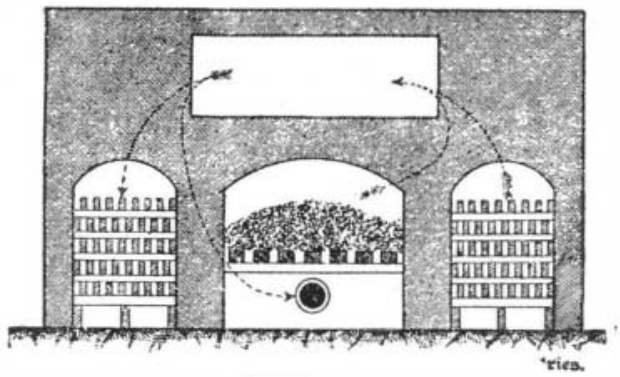

FIG. 8.

GENERAL VIEWS OF NEW FURNACE, SHOWING LONGITUDINAL AND TRANSVERSE SECTIONS AND SECTIONAL PLANS.

with the carbonic oxide produced. In the new form / in the original Siemens furnace, but in a different manof Siemens furnace the gaseous products of combus- ner. The air regenerators perform the same functions
tion from its heating chamber are delivered under the as formerly, but the heat which in the old furnaces was
ant tion from its heating chamber are delivered under the as formerly, but the heat which in the old furnaces was
grate of the producer. grate of the producer.
These gases consist of carbonic acid, water in the leposited in the gas regenerator is now utilized to
bring about the conversion of the products of combusgaseous state, and nitrogen, all in an intensely hot $\begin{aligned} & \text { bring about the conversion of the products of combus } \\ & \text { tion into combustible gases, to distill the volatile mate- }\end{aligned}$ condition. The production of carbonic acid may there- rial in the coal, and to raise these volatile constituents \begin{tabular}{l|l} 
fore be dispensed with (as a portion of the hot gaseous to a certain temperature before their arrival in the \\
products of combustion are already in that state), pro- \\
furnace chamber. The economy of the new Siemens \\
vided the heat
\end{tabular} vided the heat usually developed in its production and
necessary for its conversion into carbonic oxide is com- per cent. when coke is the fuel employed. When coal necessary for its conversion into carbonic oxide is com- per cent. when coke is the fuel employed. When coal
pensated for by the heat brought in by the products of
is used the economy will be considerably increased, becombustion. A producer so arrange converter, in which the gaseous products of combustion the original Siemens furnace is saved in this form, an diminution of the temperature of the solid fuel. Al- Figs. 7 and 8 show the relation which exists betwe though such a result may appear at first sight para- the ordinary and the new type of Siemens furnace. In doxical and unlikely, it has been proved by experience the first case the waste gases are directed through two in the working of several furnaces during the past nine
months, and may be explained by the presence in the
are partly directed through an air regenerator and months, and may be explained by the presence in the are partly directed through an air regenerator and to carry the heat necessary for the reaction.
It is possible by a very simple reasoning to explain leaving only heat sufficient for chimney draught; and gas so as to produce uniform diffusion of heat through the furnace chamber ; in both, too, the air nd gas are delivered into the furnace at a very high temperature.

e furnace may be constructed in various forms, the one shown in Figs. 1-5 having been used with success heated by means of a horseshoe flame; this form of tive gas furnaces, but its adoption is not obligatory, as the flame may be made to traverse the heating chamber from end to end in the usual manner. The same is built the gas producer or converter, $B$, of which $\mathrm{FF}^{1}$
ing are the charging hoppers and $\mathrm{NN}^{1}$ the grates. The
heating chamber
$\mathrm{E}$, adjoins the producer and rests on heating chamber ${ }_{b} \mathrm{E}$, adjoins the producer and rests on the ground, or in some cases a pit may be provided
below it. $\mathrm{CC}^{1}$ are the flues leading the combustible gas to the furnace chamber, $E$, the passage of the gas the two ends of a rocking beam, so that the outlets are opened and shut alternately to convey the gas to one or other of the ports, $\mathrm{GG}^{1}$, of the heating chamber, $\mathrm{E}$. nicating through the flues, $\mathbf{K K}^{1}$, with the regenerators, $\mathrm{AA}^{1}$. II ${ }^{1}$ are steam jets placed in the return flue for directing a portion of the waste products of combustion to the grates of the converter. furnace, and of the products of air hustion into the the regenerators to the chimney flue. $\mathrm{OO}^{1}$ are hinged caps for alternately admitting and shutting off the products of combustion from the heating ch.imber to the converter. These caps are worked automatically the same movement which closes $\mathrm{D}$ opening $\mathrm{O}^{1}$, and the same movement which closes $D$ opening ing access to the grates of the converter for clearing them.

The modus operandi of the furnace is as follows: Gas the valve, $D^{1}$, to the gas port, $G^{1}$, and into the combus-

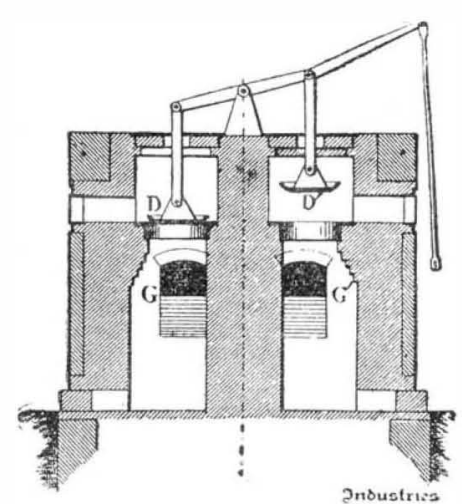

Fio.

tion chamber, $h^{1} g^{1}$. Air for combustion passes through the regenerator, $A^{1}$, the air flue, $K^{1}$, and the air port, $\mathbf{H}^{1}$, into the combustion chamber, where it meets the gas from the converter, and combustion ensues. The the products of combustion passing a way by the second combustion chamber, $h g$, and going partly through chimney flue and partly down the flue, G, whence they are drawn by means of the steam jet, $I$, through the
capped inlet under the grates, $N N^{1}$, of the producer, $B$, there to be converted into combustible gases. From time to time the direction of the flame in the furnace is reversed by manipulating the rocking beam carrying usual manner of working regenerative gas furnaces. An auxiliary steam jet is provided for the purpose of the furnace is first heated up. The new form of regenerative gas furnace has been applied in this country to the heating and welding of iron, to which uses its application is being extended in
England and abroad, while furnaces are in course of construction to apply it for puddling iron and for copper and steel melting. Altogether, ten furnaces for these purposes are in course of construction, in addiThe first furnace of this kind was constructed at the Pather Iron and Steel Company's works at Wishaw, for welding iron, and much credit is due to the proprietors for having had the enterprise and public spirit to make the first application of this improved regenerative gas furnace. The working has been eminently the first application of the furnace proves the correctpess of the principle upon which it is constructed and working during the last nine months have shown an average saving of five per cent. in waste on the weight
of the iron heated, and a saving of upward of twothirds of the weight of coal used, and a greater money saving, owing to the inferior quality of the fuel emploces fired with solid fuel. From the total saving thus realized should, however, be deducted the cost of raisng steam, for which purpose the waste heat of the old
furnaces is utilized. Allowing for separate boilers the aving effected by the use of the new system in a furnace heating eight tons of iron per shift is nearly eighteen tons of coal per week, and the money saving iron and coal exceeds $£ 1,000$ per annum.

This new furnace has also been recently applied for heating billets by the United Horse Shoe Company, of
London, and in this case the results are quite as satis- 

factory or even better than those just given, as is shown
by the accompanying table:

\begin{tabular}{|c|c|c|c|c|}
\hline Date. & $\begin{array}{l}\text { Irumber } \\
\text { of } \\
\text { chiarges } \\
\text { per } \\
\text { shaft. }\end{array}$ & $\begin{array}{c}\text { Duration } \\
\text { of } \\
\text { each shaft. }\end{array}$ & 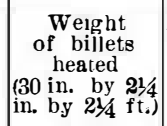 & $\begin{array}{c}\text { A verage time } \\
\text { required for } \\
\text { heating } \\
\text { to } \\
\text { welding. }\end{array}$ \\
\hline $\begin{array}{l}1889 . \\
\text { Sept. } 13 . \\
\text { Sept. } 14 . \\
\text { Sept. } 16 . \\
\text { Sept. } 17 .\end{array}$ & $\begin{array}{r}11 \\
6 \\
11 \\
11\end{array}$ & 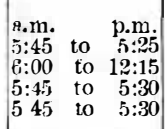 & $\begin{array}{c}\text { Minutes. } \\
21 \\
20 \\
21 \\
26\end{array}$ & $\mid \begin{array}{cc}\text { Tons. } & \text { Cwts. } \\
8 & 16 \\
4 & 16 \\
8 & 16 \\
8 & 16\end{array}$ \\
\hline
\end{tabular}

Continued below.

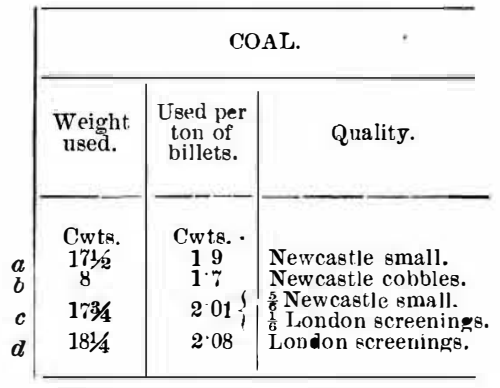

It will be noticed from these results that in this fur nace eleven charges are made in less than twel ve hours, shed state as horse shoe iron 15 cwt. per chare 8.25 tons in the day. The amount of small coal used was about $18 \mathrm{cwt}$. per shift. This is equivalent to cwt. per ton of iron heated, which, it will be admitted is a most satisfactory result : in one case the consump tion of coal was even reduced to $1 \cdot 7$ ert. per ton, each billet coming out at a full welding heat and rolling into a sound
in the table.

The following are analyses of gas made in the converters at Pather and in London respectively :

\begin{tabular}{l|l} 
Pather Co. & UNITED horse Shoe co.
\end{tabular} From Wishaw coal (nuts). IVTewcastle cobbles.

$\mathrm{CO}_{2} \ldots \ldots \ldots \ldots \ldots+46 \mathrm{CO}_{2}$

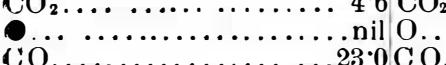

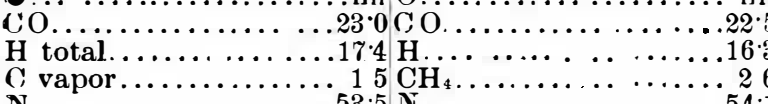

$\overline{1000}$

$\overline{1000}$

From these analyses it will be seen that the proportion of $\mathrm{CO}_{2}$ in the gas made in the converters is not greater

Besides the advantages in the saving of fuel and metal, it is desirable to call attention to the simplicity of design of the new furnace, owing to which its cost of construction is not much greater than that of a solid
fuel furnace, while its cost of maintenance is very much Its cost of construction is found to be about two-
fifths of that of the old form of regenerative gas furnace, of the same productive capacity, with separate cas producers and gas regenerators, and the space cupied below ground is also considerably reduced. A saving of labor attends the employment of the new furnace, as, owing to the producer being connected with the furnace, the same men can attend to both. and the labor of firing is reduced in proportion to the

In conclusion, the following advantages may be fuel furnaces used for heating and welding iron, viz. (1) A saving in fuel amounting to, say, two-thirds in weight, and after allowing for raising steam in separate boilers, this saving is fully equal to $5 \mathrm{cwt}$. of coa per ton of iron heated; (2) a reduction in the waste of iron equal to 5 per cent. upon the weight of metal probably a saving in labor and repairs which will furnace.

Takin a furnace to heat ten tons of iron per shift, or 110 tons per week, the following calculation give furnace:

110 tons iron at $5 \mathrm{ewt}$. per ton $=271 / 2$

coals saved at. 6 s $\ldots \ldots \ldots \ldots \ldots \ldots \ldots$......... \&8 50

110 tons iron at 5 per cent. $=51 / 2$ tons Being..........£

per week, or say $£ 1,500$ per annum. [NATURE.]

NOTES ON A RECENT VOLCANIC ISLAND IN THE PACIFIC.

IN 1867, H.M.S. Falcon reported a shoal in a position in about $20^{\circ} 20^{\prime} \mathrm{S}$. and $17.5^{\circ} 20^{\prime} \mathrm{W}$., or thirty miles west of Namuka Island of the Friendly or Tonga Group. rising from the sea at this spot.
In 1885 a volcanic island rose from the sea during a submarine eruption on October 14 , which was first reported by the Janet Nichols. a passing steamer, to be two miles long and about 250 feet high

The U. S.S. Mohican passed it in 1885, and from calculation founded on observations in passing, gave its length as $1 \frac{4}{10}$ miles, height 165 feet. The crater was on
the eastern end, and dense columns of smoke were ris ing from it.

ing from it. 1887 the French man-of-war Decres reported it height to be 290 feet. In the same year an English yacht, the Sybil. passed
it, and a sketch was made by the owner, H. Tufnell,

Esq, which is here produced. mapped, and the surronnding sea sounded
It is now $1 \frac{1}{10}$ mile long and $\frac{9}{10}$ of a mile wide, of the bable that its existence as an island will be short unless shape given in the accompanying plan. The southern a hard core is yet revealed.

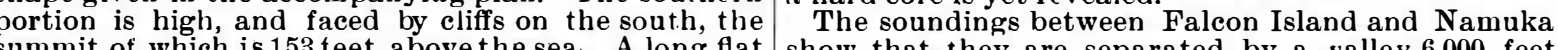
summit of which is 153 feet above the sea. A long flat show that they are separated by a valley 6,000 feet the is to the north from the foot of the hill. Thers, and a few blocks and volcanic bombs here and there, especially on the verge of the hill.

Under the action of the waves, raised by the almost constant southeast winds, this loose material is being rapidly removed : continual landslips take place, and summit was sorne 200 or 300 yards south ward of the summit was sorne 200 or 300 yards southward of the
present highest cliff, and that the shallow bank stretching to the south represents the original extension of the island.

Metis. Island, 73 miles north-northeast of Falcon Island is another volcanic cone that appeared a few years before the latter, but has not yet been examined.
W. J. L. WHARTON.

\section{HIGH ALTITUDES OF SOUTHERN} CALIFORNIA.

By Walter Lindley, M.D.

AU ¥UST 26, 1888, in company with a friend, I left Los As far as can be judged from Mr. Tufnell's sketch Angeles for the San Jacinto monntains. A four hours' from the northwest and that of the Egeria from the ride by rail took us to the tow of San Jacinto, south-southeast, considerable changes have taken where we were met by a patient of mire whom I had
place in two years, the different summits shown in considered to be at death's door from phthisis. He was

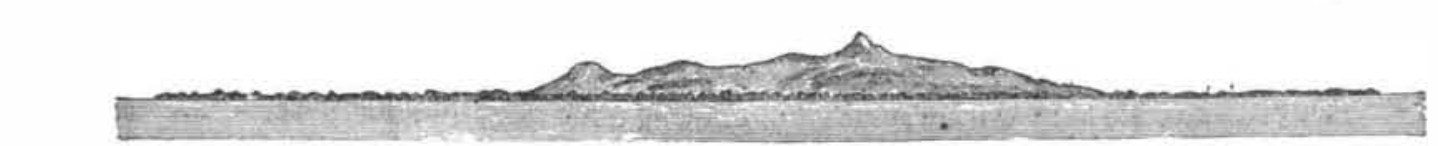

By H Zufnell, Esq., I887, bearing S.E. about 2 miles.

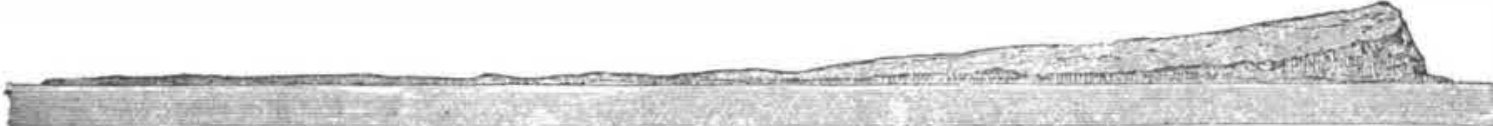

By "Escra," $18 \delta a$, bearing E. It mile.

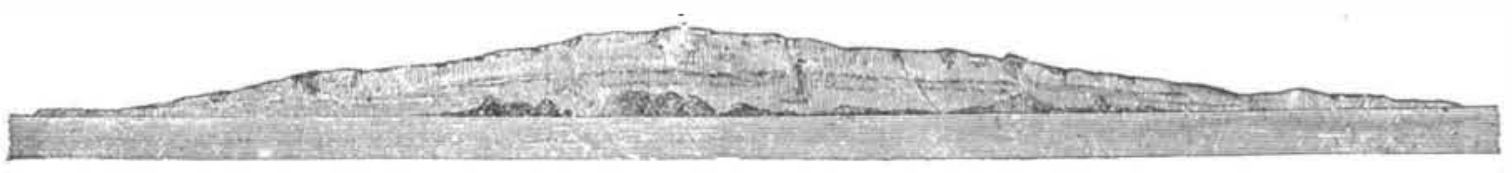

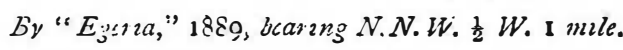

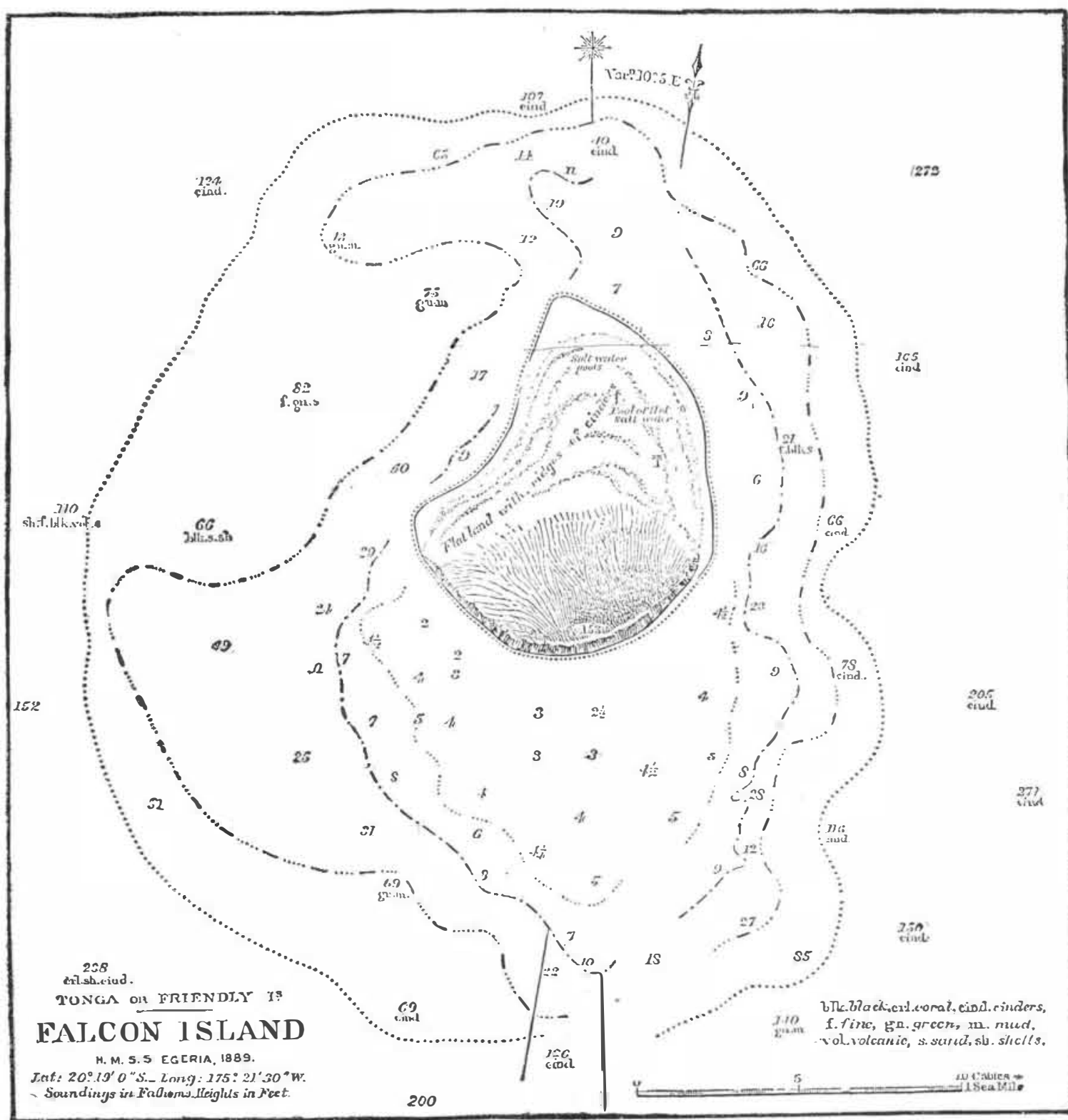

the former having disappeared as the sea has eaten a post office clerk in Kansas City, and came to me way the cliffs.
nearly four years ago with daily rise of temperature to nearly four years ago with daily rise of temperature to
The flat to the north seems to be partly due to redis- $103^{\circ}$, night sweats, hard cough, purulent expectoration, tribution under the lee of the island of the material marked emaciation, dullness in left apex, rales quite removed from the southern face. It is crossed by curv- general over both lungs. He remained quite close to
ed ridges from 3 to 12 feet high, which Commander the coast for a year, but lost ground, and suddenly deOldham considers to have been formed as high beaches termined to go to San Jacinto where he "took up" a during spring tides and strong winds, the flat ground piece of government land. There was a steady improvement almost from the first. He has this season
worked in the hay field. While he is by no means a \begin{tabular}{l|l} 
worked in the hay field. While he is by no means a \\
whe island is thus gaining on one side while losing \\
well man yet the change for the better has been
\end{tabular} The island is thus gaining on one side while losing
well man, yet the change for the better has been
wonderful. San Jacinto has an altitude of about 1,400 tial recovery will probably cease. A little steam issuing from cracks in the southern $\begin{aligned} & \text { numerous consumptives claim they gain most during } \\ & \text { num }\end{aligned}$

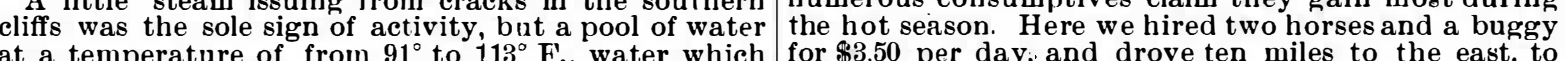
at a temperature of from $91^{\circ}$ to $113^{\circ} \mathrm{F}$., water which for $\$ 3.50$ per day, and drove ten miles to the east, to
what is called "the foot of the grade," where we stayed rose in a hole dug in the flat of a temperature of what is called "the foot of the grade," where we stayed
$128^{\circ} \mathrm{F}$, and a temperature of $100^{\circ} \mathrm{F}$. in a hole dug
over night. The accommodations would have been half way up the slope, also show that the island still $\begin{aligned} & \text { over night. } \\ & \text { real good but for the fact that the beds were all en- }\end{aligned}$ hat has filtered through the loose ashes, and it rose straw pile in the barn, but the food was good, and, like and fell with the tide.
the straw, was clean.
At 5 o'clock A.M. the next day we started up the

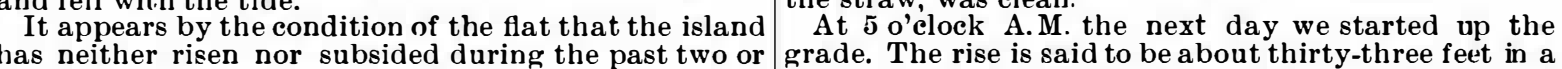

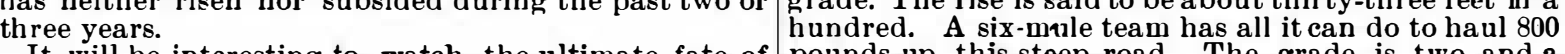
It will be interesting to watch the ultimate fate of pounds up this steep road. The grade is two and a
this last addition to the Pacific isles, but it seems pro- half miles long, and it usually takes at least three 